\title{
Tourism and Economic Growth in Turkey: Fourier Approach
}

\author{
Mustafa Orhan ÖZER \\ Anadolu Üniversitesi, AÖF, İktisadi ve İdari Programlar Bölümü, \\ mustafaorhanozer@anadolu.edu.tr,ORCID: 0000-0002-3222-9913
}

\begin{abstract}
This study deals with the relationship between tourism revenues and economic growth in Turkey over the period 2003Q1-2019Q3 within the framework of Fourier approach. The results of the Fourier ADF unit root test show that the two variables are I(1). Upon this, the Fourier ADL and the Hidden Fourier ADL cointegration tests are applied to investigate the existence of long-term relationship among the aforementioned variables. According to the results of cointegration tests, there is a unidirectional long-term relationship running from economic growth to tourism revenues. Finally, long-term coefficients are estimated through the FMOLS method. When economic growth increases $1 \%$, tourism revenues increase $0.67 \%$ considering raw data. According to the asymmetric components of the variables, when economic growth increases $1 \%$, tourism revenues increase $1.41 \%$.
\end{abstract}

Keywords: Tourism Revenues, Economic Growth, Fourier Approach, Turkey JEL Classification Codes: C22, L83, O40, O50

\section{Türkiye’de Turizm ve Ekonomik Büyüme: Fourier Yaklaşımı}

$\ddot{\mathbf{O z}}$

Bu çalışma Türkiye'de 2003Q1-2019:Q3 dönemi için turizm gelirleri ve ekonomik büyüme arasındaki ilişkiyi Fourier yaklaşımı çerçevesinde ele almaktadır. Fourier ADF birim kök testine ait sonuçlar iki değişkenin de I(1) olduğunu göstermektedir. Bunun üzerine, söz konusu değişkenler arasındaki uzun dönemli ilişkinin varlığını araştırmak için Fourier ADL ve Fourier ADL saklı eşbütünleşme testleri uygulanmıştır. Eşbütünleşme testlerinden elde edilen sonuçlara göre, uzun dönemde ekonomik büyümeden turizm gelirlerine doğru olmak üzere tek yönlü bir ilişki bulunmaktadır. Son olarak, uzun dönem katsayıları FMOLS yöntemi aracılığıyla tahmin edilmiştir. Ham veriler dikkate alındığında, ekonomik büyümede meydana gelen yüzde birlik bir artış turizm gelirlerinin yüzde 0.67 artmasına neden olmaktadır. Değişkenlerin asimetrik bileşenleri dikkate alındığında ise ekonomik büyümede görülen yüzde birlik bir artış turizm gelirlerinin yüzde 1.41 artmasına yol açmaktadır.

Anahtar Kelimeler: Turizm Gelirleri, Ekonomik Büyüme, Fourier Yaklaşımı, Türkiye JEL Sınıflandırma Kodları: C22, L83, O40, O50 


\section{Introduction}

There are four different hypotheses regarding the relationship between tourism development and economic growth. The first is the "tourism-led growth hypothesis", which alleges that there is a unidirectional relationship between variables from tourism development to economic growth. According to the "growth-driven tourism" or "supply-side" hypothesis, only economic growth affects tourism (Jackman and Lorde, 2012, p. 206). The third and fourth hypothesis imply that there is a bilateral relationship and no long-term relationship between the relevant variables, respectively. This study attempts to determine which of these four hypotheses is valid for Turkey.

Turkey is among the most important tourism centers of the world because of its ancient history, rich culture and natural wonders. The current account deficit and unemployment rate are at high levels in this country. Tourism revenues play a critical role in reducing these problems. Over and above this, it is generally accepted that tourism promotes economic growth. Under these circumstances, it is not possible to underestimate the potential positive effects of the tourism sector on the Turkish economy. However, as mentioned before, the relationship between tourism and economic growth can occur in different ways.

Tablo 1: Tourism Statistics of Turkey

\begin{tabular}{|c|c|c|c|c|}
\hline Years & $\begin{array}{c}\text { Tourist } \\
\text { Arrivals }\end{array}$ & $\begin{array}{c}\text { Tourism } \\
\text { Receipts } \\
\mathbf{( \$ 1 0 0 0 )}\end{array}$ & $\begin{array}{c}\text { Average } \\
\text { Expenditure } \\
\mathbf{( \$ )}\end{array}$ & $\begin{array}{c}\text { Tourism } \\
\text { receipts in } \\
\text { GDP }(\boldsymbol{\%})\end{array}$ \\
\hline 2003 & 16463623 & 13854866 & 850 & 4,4 \\
\hline 2004 & 20753734 & 17076607 & 843 & 4,2 \\
\hline 2005 & 25045142 & 20322111 & 842 & 4,1 \\
\hline 2006 & 23924023 & 18593951 & 803 & 3,4 \\
\hline 2007 & 27239630 & 20942500 & 770 & 3,1 \\
\hline 2008 & 31137774 & 25415067 & 820 & 3,3 \\
\hline 2009 & 31759816 & 25064482 & 783 & 3,9 \\
\hline 2010 & 32997308 & 24930997 & 755 & 3,2 \\
\hline 2011 & 36769039 & 28115692 & 778 & 3,4 \\
\hline 2012 & 37715225 & 29007003 & 795 & 3,3 \\
\hline 2013 & 39860771 & 32308991 & 824 & 3,4 \\
\hline 2014 & 41627246 & 34305903 & 828 & 3,7 \\
\hline 2015 & 41114069 & 31464777 & 756 & 3,7 \\
\hline 2016 & 30906680 & 22107440 & 705 & 2,6 \\
\hline 2017 & 37969824 & 26283656 & 681 & 3,1 \\
\hline 2018 & 46112592 & 29512926 & 647 & 3,8 \\
\hline 2019 & 51747198 & 34520332 & 666 & 4,6 \\
\hline
\end{tabular}

Source: Republic of Turkish Ministry of Culture and Tourism 
Tourism industry of Turkey has come a long way in recent years. According to the statistics of Republic of Turkish Ministry of Culture and Tourism (2020), international tourism receipts enhanced from 13.8 billion dollars in 2003 to 34.5 billion dollars in 2019. The number of international tourist arrivals which was 16.4 million in 2003, have reached 51.7 million in 2019. Advantageous exchange rate has been a considerable degree effective in this success (UNWTO, 2020). On the other hand, international tourism receipts grew by 5.9 percent although the number of international tourist arrivals increased by 7.4 percent on average in each year. Moreover, average spending decreased dramatically in this period.

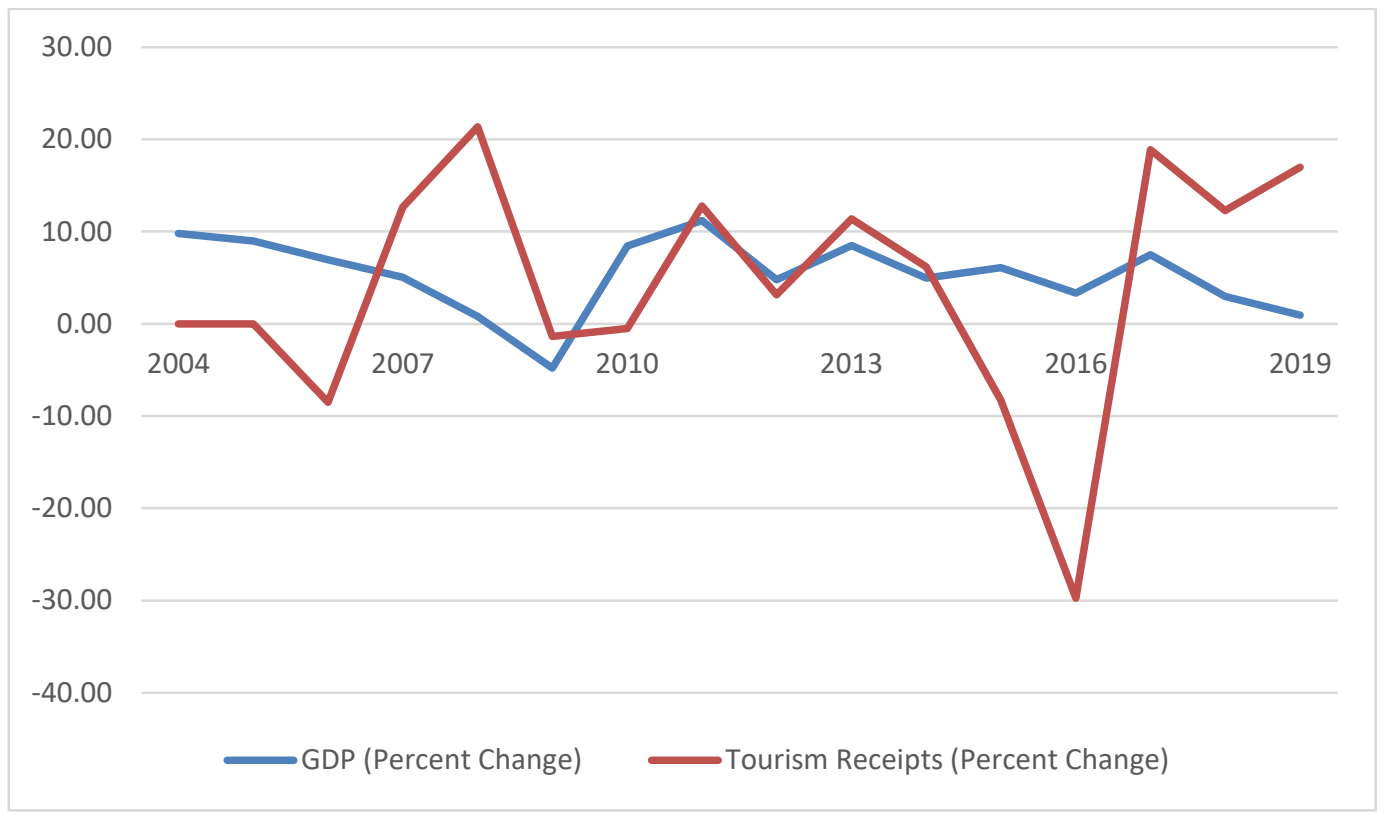

Figure 1: Tourism and Economic Growth in Turkey

Source: Republic of Turkish Ministry of Culture and Tourism (Tourism Receipts) and The Central Bank of the Republic of Turkey (GDP).

Figure 1 shows the relationship between tourism and economic growth in Turkey over the period 2004-2019. During this period, GDP shrank only once due to the global financial crisis of 2008-2009. Tourism receipts were negatively affected by both the global crisis and the aircraft crisis between Turkey and Russia in november 2015. It is estimated that the aircraft crisis cost about 2.1 billion dollars to Turkish tourism (Şahin, Konak and Karaca, 2017, p. 476). The impact of the global crisis was less costly (Gök, Tuna, Binbaşığlu and Kuluşakl1, 2012, p. 1057). It is noteworthy that the variables moved together in the 2009-2014 subperiod between the two crises.

Unlike other studies, the Fourier ADL and the hidden Fourier ADL cointegration tests are employed to investigate the relationship between tourism revenues and 
economic growth in this study. Cointegration tests based on Fourier functions capture unknown form and number of structural breaks in the variables (Tsong, Lee, Tsai and $\mathrm{Hu}, 2016$, p. 1087). Furthermore, these tests do not need to estimate a large number of parameters (Banerjee, Arcabic and Lee, 2017, p. 115). The hidden Fourier ADL cointegration test separates the asymmetric impacts of the positive and negative components on the long-term relationship between the series (Yılanc1, Özgür and Görüş, 2019, p. 2). Therefore, this test not only takes into account structural breaks but also unveils the possible hidden relationships.

The rest of the paper is organised as follows: the second section presents the related empirical literature. The third section gives information about the data and introduces empirical model and econometric methodology. The fourth section reports empirical findings. The last section finalizes the paper.

\section{Literature Review}

The literature on the relationship between tourism and economic growth can be epitomized as follows:

Durbarry (2004) examines the link between tourism development and economic expansion in Mauritius, a small island country in eastern Africa, utilizing data from 1952 to 1999. The paper employs Johansen cointegration and Granger causality tests. Empirical findings show that tourism development encourages economic growth. Aratuo, Etienne, Gebremedhin and Fryson (2019) examine the relationship between tourism arrivals and GDP in United States over the period 1996:01-2016:03 using monthly data. They use ARDL bound testing approach and Granger causality test. This study reveals that tourism positively affects economic growth not only in the long-term but also in the short-term.

Oh (2005) investigates the relationship between tourism revenues and economic growth in South Korea for the period 1975Q1-2001Q1 through Engle-Granger cointegration and Granger causality tests. According to the cointegration test results, there is no long-term relationship between these variables. However, results of the causality test reveal that there is a one-way causality runs from economic growth to tourism revenues. Phiri (2016) peruses the link between tourism development and economic expansion in South Africa, utilizing data from 1994 to 2014. The study employs Engle-Granger and Enders-Granger cointegration tests. According to the results of Engle-Granger cointegration test, tourist arrivals supports economic growth. However, results of Enders-Granger cointegration test reveal that there is no relationship between the aforementioned variables.

Seetanah (2011) examines the impacts of tourism development on economic growth in 19 island countries for the period 1990 to 2007 using GMM estimator. According to the findings, tourism supports economic growth in these countries. 
Furthermore, causality test demonstrates that there is a bidirectional relationship between the two variables. Antonakakis, Dragouni and Filis (2015) analyze the relationship between tourism performance and economic growth in 10 selected European economies during the period 1995-2012 using the spillover index approach. The study provides three important results. The way and size of relationship changes in the course of time. The relationship is shaped by economic crisis. The impact of economic crises on this relationship is more pronounced in weak countries such as Spain, Portugal, Greece and South Cyprus. Sağlam and Egeli (2018) investigate the selected Commonwealth of Independent States (Armenia, Azerbaijan, Kazakhstan, Kyrgyzstan Russia and Ukraine) for the period 1995-2015 with the Durbin-Hausman cointegration and the DumitrescuHurlin causality tests. The first test reveals that the variables are cointegrated and the second test shows that there is only one-way relationship from GDP per capita to tourism receipts.

There are many studies which are examining the relationship between tourism and economic growth for Turkey. Gündüz and Hatemi-J (2005), Zortuk (2009), Polat and Günay (2012), Çoban and Özcan (2013), Bozgeyik (2015), Kaygısız (2015), Özcan (2015), Topallı (2015), Bal, Akça and Bayraktar (2016), Gövdeli (2018), Dereli and Akiş (2019) depict that tourism encourages economic growth. Moreover, Kızılkaya, Sofuoğlu and Karaçor (2016), Altıner (2019) find that this effect is valid both in the short and long-term. However, K1zılgöl and Erbaykal (2008) argues that there is a unidirectional relationship from economic growth to tourism revenues. Bozkurt and Topçuoğlu (2013), Samırkaş and Samırkaş (2014), Kanca (2015), Beşel ve Uyğun (2017), Aytun and Akın (2019), Ballı, Sigeze and Coşkun (2020) explore that there is a bilateral relationship among the variables. On the other hand, Yavuz (2006), Katırcıoglu (2009), Yamak (2012), Kızılkaya (2018), Bingöl, Pehlivan and Han (2020) reveal that there is no relationship between the relevant variables.

\section{Data and Econometric Methodology}

\subsection{Data}

The main goal of this study is to investigate the long-term relationship between tourism revenues (LTR) and economic growth (LY) for Turkey. GDP in chain linked volume by expenditure approach are considered as an indicator of economic growth. The dataset obtained from Electronic Data Delivery System of the Central Bank of the Republic of Turkey are quarterly and covers the period 2003Q1-2019Q3. Both series are in natural logarithms.

\subsection{Fourier ADF Unit Root Test}

This study utilizes the following Fourier ADF model of Christopoulos and LeonLedesma (2010) in order to examine the stationarity of variables: 
$y_{t}=\delta_{0}+\delta_{1} \sin \left(\frac{2 \pi k t}{T}\right)+\delta_{2} \cos \left(\frac{2 \pi k t}{T}\right)+v_{t}, \quad \pi=3.1415$

where $y_{t}$ denote LTR or LY or positive and negative components of these variables. $T$ and $t$ represent number of observations and trend term, respectively. $\mathrm{k}$ indicates the number of frequencies and it is a positive integer less than six. The value that minimizes the sum of squares residual (SSR) is defined as the optimal $\mathrm{k}$. This value is determined and then the residues are obtained:

$\hat{v}_{t}=y_{t}-\hat{\delta}_{0}+\hat{\delta}_{1} \sin \left(\frac{2 \pi k^{*} t}{T}\right)+\delta_{2} \cos \left(\frac{2 \pi k^{*} t}{T}\right)$

In the next stage, the unit root test is applied on the residues:

$\Delta v_{t}=\alpha_{1} v_{t-1}+\sum_{j=1}^{p} \beta_{j} \Delta v_{t-j}+u_{t}$

Where $p$ stands for lag length and $u_{t}$ white noise error term. The null hypothesis implying that the variable contains a unit root and the alternative hypothesis that represents for the opposite are as follows:

$H_{0}: \alpha_{1}=0$

$H_{1}: \alpha_{1}<0$

The critical values required for the test are tabulated by Christopoulos and LeonLedesma (2010, p. 1083). Finally, F-test is performed to test the significance of trigonometric terms. The hypotheses are as follows:

$H_{0}: \delta_{1}=\delta_{2}=0$

$H_{1}: \delta_{1}=\delta_{2} \neq 0$

The null hypothesis implies that trigonometric terms are insignificant. F-test is employed only if the variable is stationary. The critical values required for this test are tabulated by Becker, Enders and Lee (2006, p. 389). If trigonometric terms are insignificant, ADF unit root test is implemented to the variable.

\subsection{Fourier ADL Cointegration Test}

To investigate the long-term relationship between tourism revenues and economic growth using the Fourier ADL cointegration test, the following equations are taken into account (Banerjee et al., 2017, p. 116):

$$
\begin{aligned}
& \Delta L Y_{t}=\alpha_{0}+\alpha_{1} \sin \left(\frac{2 \pi k^{*} t}{T}\right)+\alpha_{2} \cos \left(\frac{2 \pi k^{*} t}{T}\right)+\alpha_{3} L Y_{t-1}+\alpha_{4} L T R_{t-1}+ \\
& \alpha_{5} \Delta L Y_{t-1}+\alpha_{6} \Delta L T R_{t-1}+e_{t}
\end{aligned}
$$




$$
\begin{aligned}
& \Delta L T R_{t}=\beta_{0}+\beta_{1} \sin \left(\frac{2 \pi k^{*} t}{T}\right)+\beta_{2} \cos \left(\frac{2 \pi k^{*} t}{T}\right)+\beta_{3} L T R_{t-1}+\beta_{4} L Y_{t-1}+ \\
& \beta_{5} \Delta L T R_{t-1}+\beta_{6} \Delta L Y_{t-1}+\varepsilon_{t}
\end{aligned}
$$

where $e_{t}$ and $\varepsilon_{t}$ are error terms. The k value minimizing the Akaike Information Criteria (AIC) is defined as optimal k. As seen in equations (8) and (9), lags of $\triangle L Y$ and $\triangle L T R$ are included in the model to eliminate possible serial correlation in $e_{t}$ and $\varepsilon_{t}$. The hypotheses for this two models are as follows:

$$
\begin{array}{ll}
H_{0}: \alpha_{3}=0, & H_{0}: \beta_{3}=0 \\
H_{1}: \alpha_{3}=0, & H_{1}: \beta_{3}=0
\end{array}
$$

The null hypotheses imply that the variables are not cointegrated while the alternative hypotheses stand for that they are cointegrated. Banerjee et al. (2017, p. 117) recommend that t-statistic are used for the Fourier ADL Cointegration Test. So, the test statistics are identified by:

$$
t_{A D L}^{F}=\frac{\widehat{\alpha}_{3}}{s e\left(\widehat{\alpha}_{3}\right)}, \quad t_{A D L}^{F}=\frac{\widehat{\beta}_{3}}{s e\left(\widehat{\beta}_{3}\right)}
$$

where $\hat{\alpha}_{3}$ and $\hat{\beta}_{3}$ are the ordinary least squares estimators of $\alpha_{3}$ and $\beta_{3}$, respectively. $\operatorname{se}\left(\widehat{\alpha}_{3}\right)$ and $\operatorname{se}\left(\widehat{\beta}_{3}\right)$ are standart errors of $\hat{\alpha}_{3}$ and $\hat{\beta}_{3}$. The critical values required for this test are tabulated by Banerjee et al. (2017).

\subsection{Hidden Fourier ADL Cointegration Test}

Y1lanc1 et al. (2019) suggest the hidden Fourier ADF cointegration test to unveil the hidden relationship between the variables. To show this test, $L Y_{t}$ and $L T R_{t}$ are identified by (Y1lanc1 et al., 2019, p. 3):

$$
\begin{aligned}
& L Y_{t}=L Y_{t-1}+e_{t}=L Y_{0}+\sum_{i=1}^{t} e_{i}^{+}+\sum_{i=1}^{t} e_{i}^{-} \\
& L T R_{t}=L T R_{t-1}+\varepsilon_{t}=L T R_{0}+\sum_{i=1}^{t} \varepsilon_{i}^{+}+\sum_{i=1}^{t} \varepsilon_{i}^{-}
\end{aligned}
$$

where $e_{i}^{+}, \varepsilon_{i}^{+}$symbolize positive components and $e_{i}^{-}, \varepsilon_{i}^{-}$negative components. $L Y_{0}$ and $L T R_{0}$ stand for the start values for $L Y$ and $L T R$, respectively. Positive and negative components are identified in a cumulative form as follows:

$$
L Y_{t}^{+}=\sum_{i=1}^{t} e_{i}^{+}, L Y_{t}^{-}=\sum_{i=1}^{t} e_{i}^{-}, L T R_{t}^{+}=\sum_{i=1}^{t} \varepsilon_{i}^{+}, L T R_{t}^{-}=\sum_{i=1}^{t} \varepsilon_{i}^{-}
$$

The following equations are taken into account to run the hidden Fourier ADL cointegration test (Y1lanc1 et al., 2019, p. 4): 
$\Delta L Y_{t}^{+}=\alpha_{0}+\alpha_{1} \sin \left(\frac{2 \pi k^{*} t}{T}\right)+\alpha_{2} \cos \left(\frac{2 \pi k^{*} t}{T}\right)+\alpha_{3} L Y_{t-1}^{+}+\alpha_{4} L T R_{t-1}^{+}+$

$\alpha_{5} \Delta L Y_{t-1}^{+}+\alpha_{6} \Delta L T R_{t-1}^{+}+\zeta_{t}$

$\Delta L T R_{t}^{+}=\beta_{0}+\beta_{1} \sin \left(\frac{2 \pi k^{*} t}{T}\right)+\beta_{2} \cos \left(\frac{2 \pi k^{*} t}{T}\right)+\beta_{3} L T R_{t-1}^{+}+\beta_{4} L Y_{t-1}^{+}+$

$\beta_{5} \Delta L T R_{t-1}^{+}+\beta_{6} \Delta L Y_{t-1}^{+}+\eta_{t}$

$\Delta L Y_{t}^{-}=\gamma_{0}+\gamma_{1} \sin \left(\frac{2 \pi k^{*} t}{T}\right)+\gamma_{2} \cos \left(\frac{2 \pi k^{*} t}{T}\right)+\gamma_{3} L Y_{t-1}^{-}+\gamma_{4} L T R_{t-1}^{-}+$

$\gamma_{5} \Delta L Y_{t-1}^{-}+\gamma_{6} \Delta L T R_{t-1}^{-}+\xi_{t}$

$\Delta L T R_{t}^{-}=\theta_{0}+\theta_{1} \sin \left(\frac{2 \pi k^{*} t}{T}\right)+\theta_{2} \cos \left(\frac{2 \pi k^{*} t}{T}\right)+\theta_{3} L T R_{t-1}^{-}+\theta_{4} L Y_{t-1}^{-}+$

$\theta_{5} \Delta L T R_{t-1}^{-}+\theta_{6} \Delta L Y_{t-1}^{-}+\varsigma_{t}$

where $\zeta_{t}, \eta_{t}, \xi_{t}$ and $\zeta_{t}$ symbolize error terms. The procedure which is practiced in the next steps is identical to the Fourier ADL cointegration test (Y1lanc1 et al., 2019).

\section{Empirical Findings}

Banerjee et al. (2017) stated that all variables must be integrated I(1), which is a required specification for the Fourier ADL cointegration test. Therefore, the Fourier ADF unit root test is applied to examine whether the two variables contain a unit root or not and the results are provided in Table 2 .

Table 2: Fourier ADF Unit Root Test Results

\begin{tabular}{|c|c|c|c|c|c|}
\hline Variables & $\mathbf{k}$ & Min SSR & $\begin{array}{c}\text { Fourier } \\
\text { ADF }\end{array}$ & ADF & F-statistic \\
\hline LY & 1 & 1.793 & -1.862 & & $45.102^{*}$ \\
\hline LTR & 1 & 3.671 & -1.269 & & $21.817^{*}$ \\
\hline DLY & 3 & 0.006 & $-3.179^{* *}$ & & $10.047^{*}$ \\
\hline DLTR & 2 & 0.637 & $-6.212^{*}$ & $-5.983^{*}$ & 3.988 \\
\hline
\end{tabular}

Note: ${ }^{*},{ }^{* *}$ indicate that the null hypothesis is rejected at the $1 \%$ and $5 \%$ significance levels, respectively. Fourier ADF critical values are $-4.43(1 \%),-3.85(5 \%),-3.52(10 \%) ;-3.95(1 \%)$, $3.28(5 \%),-2.91(10 \%) ;-3.70(1 \%),-3.06(5 \%),-2.71(10 \%)$ for $\mathrm{k}=1, \mathrm{k}=2$ and $\mathrm{k}=3$, respectively. Critical values for F-test are $6.730(1 \%), 4.929(5 \%)$ and $4.133(\% 10)$.

As can be seen in Table 2, the Fourier ADF unit root test results show that LY and LTR are not stationary at the levels. Then, the Fourier ADF unit root test is applied for DLY and DLTR, which are the first difference of LY and LTR, respectively. According to the F-test, trigonometric terms are significant for all variables except DLTR. Thus, the ADF unit root test is performed for this variable. To summarize, results obtained from stationary analysis demonstrate that the two variables are I(1). Accordingly, it is possible to run the Fourier ADL 
cointegration test to investigate the existence of the long-term relationship between LY and LTR.

Table 3: Fourier ADL Cointegration Test Results

\begin{tabular}{|c|c|c|c|c|c|c|}
\hline $\begin{array}{c}\text { Dependent } \\
\text { Variable }\end{array}$ & $\begin{array}{c}\text { Independent } \\
\text { Variable }\end{array}$ & $\mathbf{k}$ & $\begin{array}{c}\text { Lag of } \\
\text { Dependent } \\
\text { Variable }\end{array}$ & $\begin{array}{c}\text { Lag of } \\
\text { Independent } \\
\text { Variable }\end{array}$ & $\begin{array}{c}\text { Min } \\
\text { AIC }\end{array}$ & $\begin{array}{c}\text { Fourier ADL } \\
\text { Cointegration } \\
\text { Test Statistic }\end{array}$ \\
\hline LY & LTR & 1 & 1 & 1 & -6.976 & -1.635 \\
\hline LTR & LY & 2 & 1 & 3 & -3.894 & $-3.811^{* *}$ \\
\hline
\end{tabular}

Note: ${ }^{* *}$ indicates that the null hypothesis is rejected at the 5\% significance level. Fourier ADL critical values are $-4.73(1 \%),-4.09(5 \%),-3.76(10 \%)$ for $\mathrm{k}=1$ and $-4.44(1 \%),-3.75(5 \%),-3.37$ (10\%) for $\mathrm{k}=2$.

Table 3 illustrates the results of the Fourier ADL cointegration test. The null hypothesis implying that variables are not cointegrated is not rejected in the first model where LY is the dependent variable. On the other hand, LTR is the dependent variable in the second model and the null hypothesis is rejected. Fourier ADL cointegration test results reveal that there is a unidirectional longterm relationship from LY to LTR.

This study also employs hidden Fourier ADL cointegration test to determine the possible hidden long-term relationship between tourism revenues and economic growth. Y1lanci et al. (2019) emphasized that positive and negative components of the variables must be integrated I(1) to carry out this test like Fourier ADL cointegration test. Thus, the Fourier ADF unit root test is performed for these components, and results in presented Table 4.

Table 4: Results of Fourier ADF Unit Root Test for Positive and Negative Components

\begin{tabular}{|c|c|c|c|c|c|}
\hline Variable & $\mathbf{k}$ & Min SSR & $\begin{array}{c}\text { Fourier } \\
\text { ADF }\end{array}$ & ADF & F-statistic \\
\hline LY $^{+}$ & 1 & 2.087 & 0.041 & & $50.197^{*}$ \\
\hline LTR $^{+}$ & 1 & 8.700 & -2.645 & & $20.406^{*}$ \\
\hline LY $^{-}$ & 1 & 0.026 & -0.808 & & $69.805^{*}$ \\
\hline LTR $^{-}$ & 1 & 2.160 & -1.660 & & $27.792^{*}$ \\
\hline DLY $^{+}$ & 3 & 0.003 & $-3.018^{* * *}$ & & $11.439^{*}$ \\
\hline DLTR $^{+}$ & 1 & 0.554 & $-6.179^{*}$ & $-6.024^{*}$ & 3.350 \\
\hline DLY $^{-}$ & 5 & 0.001 & $-3.773^{*}$ & $-3.606^{*}$ & 4.127 \\
\hline DLTR $^{-}$ & 5 & 0.039 & $-4.296^{*}$ & $5.206^{* *}$ \\
\hline
\end{tabular}

Note: ${ }^{*}{ }^{* * * * * *}$ indicate that the null hypothesis is rejected at the $1 \%, 5 \%$ and $10 \%$ significance levels, respectively. Fourier ADF critical values are $-4.43(1 \%),-3.85(5 \%),-3.52(10 \%) ;-3.70$ (1\%), $-3.06(5 \%),-2.71(10 \%) ;-3.55(1 \%),-2.90(5 \%),-2.56(10 \%)$ for $\mathrm{k}=1, \mathrm{k}=3$ and $\mathrm{k}=5$, respectively. Critical values for F-test are $6.730(1 \%), 4.929(5 \%)$ and $4.133(\% 10)$. 
Table 4 shows that all positive and negative components have a unit root at the levels. We then implement again the Fourier ADF unit root test to these components at the first differences. However, according to the F-test, null hypothesis is not rejected for DLTR ${ }^{+}$and DLY. So, the ADF unit root test is applied for these components. The results of stationary analysis indicate that all four components are I(1). Thereby, it is possible to utilize the hidden Fourier ADL cointegration test to examine the presence of hidden relationship between the variables.

Table 5: Hidden Fourier ADL Cointegration Test Results

\begin{tabular}{|c|c|c|c|c|c|c|}
\hline $\begin{array}{c}\text { Dependent } \\
\text { Variable }\end{array}$ & $\begin{array}{c}\text { Independent } \\
\text { Variable }\end{array}$ & $\mathbf{k}$ & $\begin{array}{c}\text { Lag of } \\
\text { Dependent } \\
\text { Variable }\end{array}$ & $\begin{array}{c}\text { Lag of } \\
\text { Independent } \\
\text { Variable }\end{array}$ & $\begin{array}{c}\text { Min } \\
\text { AIC }\end{array}$ & $\begin{array}{c}\text { Hidden } \\
\text { Fourier ADL } \\
\text { Cointegration } \\
\text { Test Statistic }\end{array}$ \\
\hline LY $^{+}$ & LTR $^{+}$ & 1 & 1 & 1 & -7.514 & -1.238 \\
\hline LTR $^{+}$ & LY $^{+}$ & 2 & 1 & 3 & -4.601 & $-3.997^{* * *}$ \\
\hline LY $^{-}$ & LTR $^{-}$ & 1 & 3 & 1 & -8.349 & -2.637 \\
\hline LTR $^{-}$ & LY- $^{-}$ & 2 & 1 & 3 & -4.830 & -1.600 \\
\hline
\end{tabular}

Note: ${ }^{* *}$ indicates that the null hypothesis is rejected at the $5 \%$ significance level. Hidden Fourier ADL critical values are $-4.73(1 \%),-4.09(5 \%),-3.76(10 \%)$ for $\mathrm{k}=1$ and $-4.44(1 \%),-3.75(5 \%)$, $3.37(10 \%)$ for $\mathrm{k}=2$.

The results from hidden Fourier ADL cointegration test are illustrated in Table 5. This test demonstrates that there is no cointegration considering negative components because the hidden Fourier ADL cointegration test statistics are smaller than critical values in absolute value. On the other hand, there is a unidirectional long-term relationship running from $\mathrm{LY}^{+}$to $\mathrm{LTR}^{+}$. This finding is similar to the results from the Fourier ADL cointegration test. Finally, the longrun coefficients are estimated by the FMOLS estimator and are reported in Table 6.

Table 6: Results of FMOLS Method

\begin{tabular}{|c|c|c|c|c|}
\hline $\begin{array}{c}\text { Dependent } \\
\text { Variable }\end{array}$ & $\begin{array}{c}\text { Independent } \\
\text { Variable }\end{array}$ & Coefficient & $\begin{array}{c}\text { Standard } \\
\text { Error }\end{array}$ & t-statistic \\
\hline \multirow{2}{*}{ LTR } & Constant & -5.741 & 3.125 & $-1.836^{* * * *}$ \\
\cline { 2 - 5 } & LY & 0.677 & 0.160 & $4.232^{*}$ \\
\hline \multirow{2}{*}{ LTR $^{+}$} & Constant & 1.056 & 0.050 & $20.796^{*}$ \\
\cline { 2 - 5 } & LY $^{+}$ & 1.415 & 0.086 & $16.424^{*}$ \\
\hline
\end{tabular}

Note: ${ }^{*},{ }^{* * *}$ indicate statistical significance at $1 \%$ and $10 \%$, respectively.

Table 6 shows that all estimated coefficients are significant. When the LY increases $1 \%$, the LTR increases $0.67 \%$ considering raw data. According to the asymmetric components of the variables, when LY increases $1 \%$, LTR increases $1.41 \%$. So, economic growth has a positive impact on tourism revenues in Turkey. 


\section{Conclusion}

This paper attempts to analyze the relationship between tourism revenues and economic growth in Turkey for the period 2003Q1-2019Q3. Firstly, the Fourier $\mathrm{ADF}$ unit root test is run to investigate the stationarity of the variables. The results of the unit root test indicate that both variables are stationary at the first variations while they have a unit root at the levels. Then, the Fourier ADL unit root test is implemented to examine the relationship among the aforementioned variables. The results reveal that there is a unidirectional long-term relationship running from economic growth to tourism revenues. The hidden Fourier ADL cointegration test also confirms these findings. Finally, the FMOLS method is employed to estimate long-term coefficients. One percent increase in economic growth leads to 0.67 percent and 1.41 percent increase in tourism revenues in the context of raw data and positive components, respectively.

This study shows that tourism-led growth hypothesis is invalid for Turkey in longterm. In other words, the increase or decrease in tourism revenues does not have a direct impact on economic growth. Therefore, it is not recommended to prefer tourism policies to promote economic growth as a policy tool. On the other hand, the results reveal that supply-side hypothesis is valid in Turkey, supporting the findings of Kızılgöl and Erbaykal (2008). Economic growth positively affects tourism receipts. For this reason, Turkey should focus on sustainable and stable economic growth to achieve more tourism revenues. For further studies in this topic, the reasons why tourism receipts do not encourage economic growth can be investigated and it may be useful to search for solutions. 


\section{References}

Altıner, A. (2019). Turizm ve ekonomik büyüme ilişkisi: Türkiye örneği (19692018). Anadolu İktisat ve Issletme Dergisi, 3(2), 114-133.

Antonakakis, N., Dragouni, M. and Filis, G. (2015). How strong is the linkage between tourism and economic growth in Europe? Economic Modelling, $38(1), 142-155$.

Aratuo, D. N., Etienne, X. L., Gebremedhin, T. and Fryson, D. M. (2019). Revisiting the tourism-economic growth nexus: evidence from the United States. International Journal of Contemporary Hospitality Management, 31(9), 3779-3798.

Aytun, C. and Akın, C. S. (2019). The relationship between tourism income, tourism expenditure and gross domestic product in Turkey: a gradual shift causality application. O. Uçan, (Ed.), In book: Discussions between Economic Agents: Time Series Analysis in Social Sciences, (p.p. 5-31), Publisher: Iksad Publishing House.

Bal, H., Akça, E. E. and Bayraktar, M. (2016). The contribution of tourism to economic growth: a research on the Turkey. Journal of Academic Approaches, 7(1), 1-20.

Ballı, E., Sigeze, Ç. and Coşkun, N. (2020). Türkiye'de turizm ve ekonomik büyüme arasındaki doğrusal olmayan nedensellik ilişkisi. Çankırı Karatekin Üniversitesi İktisadi ve İdari Bilimler Fakültesi Dergisi, 10(1), 97-117.

Banerjee, P., Arcabic, L. and Lee, H. (2017). Fourier ADL cointegration test to approximate smooth breaks with new evidence from crude oil market. Economic Modelling, 67(C), 114-124.

Becker, R., Enders, W. and Lee, J. (2006). A stationairy test in the presence of an unknown number of smooth breaks. Journal of Time Series Analysis, 27(3), 381-409.

Beşel, F. and Uyğun, U. (2017). The relationship between economic growth and tourism income: the case of Turkey. 3rd SCF International Conference on Economic and Social Antalya Impacts of Globalization, 5-7 October, Antalya, 15-23.

Bingöl, N., Pehlivan, C. and Han, A. (2020). Turizm gelirleri-makro değişkenler arasındaki ilişkinin Türkiye için ampirik olarak incelenmesi. EKEV Akademi Dergisi, 24(82), 245-262. 
Bozgeyik, Y. and Yoloğlu, Y. (2015). Türkiye'de turizm gelirleri ile GSYİH arasındaki ilişski: 2002-2014 dönemi, Uluslararası Sosyal Araştırmalar Dergisi, 8(40), 627-640.

Bozkurt, E. and Topçuoğlu, Ö. (2013). Türkiye'de ekonomik büyüme ve turizm ilişkisi. Gümüşhane Üniversitesi Sosyal Bilimler Elektronik Dergisi, 4(7), 91-105.

Christopoulos, D. and Leon-Ledesma, M. A. (2010). Smooth breaks and nonlinear mean reversion: post-Bretton woods real exchange rates. Journal of International Money and Finance, 29(6), 1076-1093.

Çoban, O. and Özcan, C. C. (2013). Türkiye'de turizm gelirleri-ekonomik büyüme ilişkisi: nedensellik analizi (1963-2010). Eskişehir Osmangazi Üniversitesi İktisadi ve İdari Bilimler Dergisi, 8(1), 243-261.

Dereli, D. D. and Akiş, E. (2019). Türkiye'de turizm gelirleri ile iktisadi büyüme arasındaki ilişkinin analizi (1970-2016). Atatürk Üniversitesi İktisadi ve Idari Bilimler Dergisi, 33(2), 467-478.

Durbarry, R. (2004). Tourism and economic growth: the case of Mauritius. Tourism Economics, 10(4), 389-401.

Gündüz, L. and Hatemi-J, A. (2005). Is the tourism-led growth hypothesis valid for Turkey? Applied Economics Letters, 12(8), 499-504.

Gök, A., Tuna, H., Binbaşığlu, H. and Kuluşaklı, S. (2012). 2008 y1lında meydana gelen ekonomik krizin turizm açısından değerlendirilmesi: Türkiye'nin diğer Akdeniz çanağı ülkelerine göre durumu. Turgut Özal Uluslar arası Ekonomi ve Siyaset Kongresi-II Küresel Değişim ve Demokratikleşme, 19-20 Nisan, Malatya, 1042-1060.

Gövdeli, T. (2018). Ekonomik özgürlük, turizm ve ekonomik büyüme: BRICST ülkelerinde Konya bootstrap nedensellik analizi. Uluslararası İktisadi ve İdari İncelemeler Dergisi, Prof. Dr. Harun Terzi Özel Sayısı, 379-390.

Jackman, M. and Lorde, T. (2012). Economic growth and tourism in Barbados: a test of the supply-side hypothesis. Tourismos: An International Multidisciplinary Journal of Tourism, 7(2), 203-215.

Kanca, O. C. (2015). Turizm gelirleri ve ekonomik büyüme: Türkiye örneği (1980-2013). Marmara Sosyal Araştırmalar Dergisi, 8, 1-14.

Katırcıoğlu, S. T. (2009). Revisiting the tourism-led-growth hypothesis for Turkey using the bounds test and Johansen approach for cointegration. Tourism Management, 30(1), 17-20. 
Kaygısız, A. D. (2015). Net Turizm Gelirleri ve Büyüme İlişkisi: Var ModelGranger Nedensellik Analizi. Alanya Isletme Fakültesi Dergisi, 7(2), 155164.

Kızılgöl, Ö. and Erbaykal, E. (2008). Türkiye'de turizm gelirleri ile ekonomik büyüme ilişkisi: bir nedensellik analizi. Süleyman Demirel Üniversitesi İktisadi ve İdari Bilimler Fakültesi Dergisi, 13(2), 351-360.

Kızılkaya, O., Sofuoğlu, E. and Karaçor, Z. (2016). Türkiye'de turizm gelirleriekonomik büyüme ilişkisi: ARDL sınır testi yaklaşımı. Yönetim ve Ekonomi: Celal Bayar Üniversitesi Iktisadi ve İdari Bilimler Fakültesi Dergisi, 23(1), 203-215.

Kızılkaya, O. (2018). Türkiye'de turizm gelirleri ve büyüme ilişkisinin bootstrap nedensellik testi ile incelenmesi. Dicle Üniversitesi Sosyal Bilimler Enstitüsü Dergisi, 21, 218-227.

Oh, C. O. (2005). The contribution of tourism development to economic growth in the Korean economy. Tourism Management, 26(1), 39-44.

Özcan, C. C. (2015). Turizm gelirleri-ekonomik büyüme ilişkisinin simetrik ve asimetrik nedensellik yaklaşımı ile analizi: Türkiye örneği. Erciyes Üniversitesi İktisadi ve İdari Bilimler Fakültesi Dergisi, 0(46), 177-199.

Phiri, A. (2016). Tourism and economic growth in South Africa: evidence from linear and nonlinear cointegration frameworks. Managing Global Transitions, 14(1), 31-53.

Polat, E. and Günay, S. (2012). Türkiye'de Turizm ve İhracat Gelirlerinin Ekonomik Büyüme Üzerindeki Etkisinin Testi: Eşbütünleşme ve Nedensellik Analizi. Süleyman Demirel Üniversitesi, Fen Bilimleri Enstitüsü Dergisi, 16(2), 204-211.

Sağlam, Y. and Egeli, H. A. (2018). The nexus between tourism and economic growth: case of commonwealth of independent states. Journal of Multidisciplinary Academic Tourism, 3(2), 45-51.

Samırkaş, M. and Samırkaş, M. C. (2014). Turizm sektörünün ekonomik büyümeye etkisi: Türkiye örneği. İşletme Fakültesi Dergisi, 15(1), 63-76.

Seetanah, B. (2011). Assessing the dynamic economic impact of tourism for island economies. Annals of Tourism Research, 38(1), 291-308. 
Şahin, E., Konak, F. and Karaca, S. S. (2017). Türkiye ve Rusya Arasındaki "Uçak Krizinin" Borsa İstanbul Gıda, İçecek ve Turizm Endeksleri Üzerindeki Etkisi. Business and Economics Research Journal, 8(3), 473485.

Topall1, N. (2015). Turizm sektörünün Türkiye'nin ekonomik büyümesi üzerindeki etkisi: 1963-2011. Uluslararası İktisadi ve İdari Incelemeler Dergisi, 14, 339-352.

Tsong, C. C., Lee, C. F., Tsai, L .J. and Hu, T. C. (2016). The Fourier approximation and testing for the null of cointegration. Empirical Economics, 51(3), 1085-1113.

T.C. Kültür ve Turizm Bakanlığı (2020). Turizm istatistikleri: 2019. https://yigm.ktb.gov.tr/Eklenti/69320,turizmistatistikleri2019-4pdf.pdf?0 (March 3, 2020).

UNWTO (2020). International tourism highlights: 2019 Edition. https://www.eunwto.org/doi/pdf/10.18111/9789284421152 (March 3, 2020).

Yamak, N., Tanrı̈ver, B. and Güneysu, F. (2012). Turizm - ekonomik büyüme ilişkisi: sektör bazında bir inceleme. Atatürk Üniversitesi İktisadi ve İdari Bilimler Dergisi, 26(2), 205-220.

Yavuz, N. Ç. (2006). Türkiye'de turizm gelirlerinin ekonomik büyümeye etkisinin testi: yapısal kırılma ve nedensellik analizi. Doğuş Üniversitesi Dergisi, $7(2), 162-171$.

Yılancı, V., Özgür, Ö. and Görüş, M. S. (2019). The asymmetric effects of foreign direct investment on clean energy consumption in BRICS countries: a recently introduced hidden cointegration test. Journal of Cleaner Production, 237, 1-9.

Zortuk, M. (2009). Economic impact of tourism on Turkey's economy: evidence from cointegration tests. International Research Journal of Finance and Economics, 1(25), 231-239. 